\title{
EXAMINING ORGANIZATIONAL HEALTH PRACTICES AMONG UNIVERSITIES IN THE CENTRAL REGION OF UGANDA
}

\author{
Miiro Farooq ${ }^{a}$, Azam Othman $^{b}$, Mohamad Sahari Nordin $^{c}$, \\ Mohd Burhan Ibrahim ${ }^{d}$
}

\author{
${ }^{a}$ Staff Islamic University in Uganda, Mbale, Uganda \\ International Islamic University Malaysia, Kaula Lumpur, Malaysia \\ ${ }^{\text {b,c,d }}$ International Islamic University Malaysia, Kaula Lumpur, Malaysia \\ ae-mail: miirofarooq@gmail.com \\ be-mail: azam_othman@iium.edu.my \\ ${ }^{c}$ e-mail: msahari@iium.edu.my \\ de-mail: mburhan@iium.edu.my
}

\begin{abstract}
This study gives insights on the organizational health practices applied in Ugandan universities of the central region. The paper examined four subdimensions of the construct through the use of the data obtained from eight hundred twenty $(\mathrm{N}=820)$ randomly selected sample of volunteers from the six universities that have been in existence for the last fifteen (15) years. The data were gathered using a 25- items adopted and adapted from the previous studies reviewed, a Likert scale ranging from strongly disagree to strongly agree (1-5) was used based on by Keller and Price conception of the construct. Confirmatory Factor analysis a component of structural equation modelling was employed to analyze the four subdimensions of the construct organizational health. The research findings of the empirical cross section survey reflected that there is a relationship between the four factor subdimensions; culture and climate, control and coordination, innovation/invention and accountability even though they are all distinct in nature. Meanwhile, accountability as one of the construct was eliminated from the results in figure 2 due to lower scores in the average variance explained (AVE). The results further exhibited that the four subdimensions of organizational health are reliable and valid measurements of the construct. The data generated was deemed appropriate for the study since structure equation modelling requires a big sample, and fitted the model due to the fact that all the parameter estimates were met. Lastly, the data was analysed through the use of confirmatory factor analysis and the study findings generated are an extension of the previous study findings since there was no similar study done in Uganda especially on higher education using this methodology. The study has greater implications to managers towards improvement of university staff performance and institutional transformation.
\end{abstract}

Keywords: organizational health, culture and climate, control and coordination, innovation/invention, accountability, confirmatory factor analysis, university effective performance

Paper type: Research paper 
EXAMINING ORGANIZATIONAL HEALTH PRACTICES

Miiro Farooq

Azam Othman

Mohamad Sahari Nordin

Mohd Burhan Ibrahim

\section{Introduction}

Running a university in the era of high competition has become a contentious issue with great concern among different stakeholders. Today globalization is pressuring higher education institutions to meet international standards while capturing issues like commodification, customer care, change of institutional customs, internationalization and distance learning (Mpaata, 2010). As these pressures continue to surface on the front page of university management, on the other hand governments are cutting budgets and funding to the universities every year, while the other stakeholders are pressuring the CEO's to make these organizations independent in terms of finance, development and sustainability (Hashim and Hattori, 2015). Moreover, universities' existence in the era of changes is a neverending journey with facets and elements that add up to a broad and complex mosaic (Porter and Malloch, 2002). Since running universities is essentially a continuous working process, it requires leadership and staff who are competent and skilled enough to work together and host behavior with rational thinking that encapsulates relational interactions and structural considerations that yield to good health working relations among staff (Porter and Malloch, 2015). Furthermore, the world of changes with new notions and technological advancement seem to suggest that employee morale and motivation are the key issues towards work and organizational advancement, thus to achieve both improved and quality performance, leadership must devise means through which people merge their efforts to develop new patterns of working behavior to find solutions to complex situations under which universities operate (Xenidis and Theocharous, 2014)in terms of competitiveness, employee morale, and efficiency of internal processes is a primary issue of concern for top management. Determining this status has been an issue of extensive study in various contexts, such as organizational performance, organizational behavior and culture, and, recently, organizational resilience. The research question is whether these contexts are significantly different or, in fact, they describe the same property of an organization, i.e. its inherent ability to perform and react efficiently in a dynamic business environment. A consequent question is whether this organizational property could be uniquely contextualized and used for organizational monitoring and decision-making. This paper's first aim is to define the new term of organizational health, which integrates existing concepts and largely expands the content of the term, as it is currently used in the literature. A second goal is to suggest an assessment method for organizational health that will be able to provide a metric of an organization's capacity to perform and adopt to a dynamic internal and external environment. Literature review is used to: a. Since staff's capacity in terms of knowledge and experience are the key factors towards organizational effectiveness and efficiency, leadership of educational institutions need to pay greater attention to staff welfare and harmonious working conditions so as to compete favorably and meet customer 
demands (Abrey and Smallwood, 2014; Bunoti, 2011; Porter-O'Grady and Malloch, 2002).

The above introduction therefore serves as a snapshot with an attempt to identify and describe the definition, measurement and frameworks used by previous research to unearth subdimensions of organizational health practices which universities can utilize to address their staff working conditions.

\subsection{Definition of Organizational Health}

The term organizational health was first used by Argyris in the 1950's when the then organizations were seeking ways of improving organizational culture (Schuyler, 2004). In 1960's organizations went ahead to seek for favourable ways through which human behaviours and working conditions could be managed better to enhance organizational performance and quality services (Anderson and Brown, 2010; Nicolay, 2011)in terms of competitiveness, employee morale, and efficiency of internal processes is a primary issue of concern for top management. Determining this status has been an issue of extensive study in various contexts, such as organizational performance, organizational behavior and culture, and, recently, organizational resilience. The research question is whether these contexts are significantly different or, in fact, they describe the same property of an organization, i.e. its inherent ability to perform and react efficiently in a dynamic business environment. A consequent question is whether this organizational property could be uniquely contextualized and used for organizational monitoring and decision-making. This paper's first aim is to define the new term of organizational health, which integrates existing concepts and largely expands the content of the term, as it is currently used in the literature. A second goal is to suggest an assessment method for organizational health that will be able to provide a metric of an organization's capacity to perform and adopt to a dynamic internal and external environment. Literature review is used to: a. Organizational health is defined as a solution that measures and tracks the organizational essentials that determine workers' performance. It offers a humble but influential road map for organizational leaders and managers to improve employee's quality performance (Dewar et al., 2011). Furthermore, a healthy organization can also be termed as a working environment within which human resources work with diligence and prudence with a sense of belonging and citizenship. Employees dedicate their efforts with meritocracy, valuing their knowledge and skills, plus expertise to change organizational performance in systematic, effective and highly efficient ways of the daily operations (Sarghin, 2016). A mammoth of studies has been done with efforts of devising means through which organizations can be able to provide a conducive environment for staff proper performance and effective organizational change hence developing several theories as shown in the literature.
EXAMINING ORGANIZATIONAL HEALTH PRACTICES

Miiro Farooq Azam Othman Mohamad Sahari Nordin Mohd Burhan Ibrahim 
EXAMINING ORGANIZATIONAL HEALTH PRACTICES

Miiro Farooq

Azam Othman

Mohamad Sahari Nordin

Mohd Burhan Ibrahim

\section{Literature review}

The culture of organizational health is an essential matter that is shared by all members of the organization. It helps to regulate the working environment and behaviors for human resources within an organization. Therefore, its promotion and influence yields employee effectiveness and efficiency (Lin and Lin, 2014). So, institutional leadership must give due right and attention to achieve the best from the staff's sweat towards institutional effectiveness (Sokol et al., 2015). Meanwhile, many scholars have different ways of looking at organizational health for instance; Yang states that issues of gender consideration were paramount in the improvement of institutional climate and performance satisfaction in Taiwan universities. Likewise Sokol et al., (2015) found out that organizational climate as a sub dimensional factor of organizational health was so influential on students innovation and creativity. It means that more attention given to this aspect of institutional environment the more productivity students will be. Iljins et al. (2015) state that for an institution to achieve change and effective performance it requires to have proper planning and implementation of job satisfaction, stability, team work, staff empowerment, team orientation and job description, open communication and discussion, autonomy and reward system. Meanwhile, Tiwari (2014) found out that support from supervisors, clearly stated goals of the organization, interpersonal relationship, harmonious working environment and relationship, provision of advice towards problem solving, staff rewards and promotion, readiness to change, corresponding norms with change, attractive salary and other benefits, procedures and systematic policies, clearly stated institutional priorities, provision of assistance and care whenever its necessary were the key issues toward staff efficiency and effective performance in Indian colleges and universities. Whereas in a study done in Portugal by Natario et al. (2014), it was found that leadership, assessment of staff performance, working condition, motivation, satisfaction, interpersonal relationship, job training and development, commitment and functioning teams were the ingredients used towards effective organizational health in higher education institutions. Similarly, a study done in Malaysia by Hong et al. (2014) on the same subject established that initiating structure, academic emphasis, consideration, institutional integrity, morale, resource support and upper management are dimensions for measuring organizational health. The results further revealed that staff morale is a key factor in enhancement of effective performance since it engages all the staff at several levels to interact towards execution of their responsibilities. And this was achieved through provision of enough resources and facilitation especially in both the teaching and learning process. Therefore, management must play its role within an educational environment to attain excellent academic performance so as to change the communities under which it operates(AbdulJalal et al., 2013; Altindis, 2011; Bauer and Jenny, 2012; Cameron, 1978; Dewar 
et al., 2011; Guidetti et al., 2015; Jafarzadeh, 2015; Jenaabadi and Zare Javan, 2014; Kafraj et al., 2013; Lee et al., 2014; Lejeune and Vas, 2009). In Florida Coastal University, staff performance and job satisfaction was attained through use of staff development even though some challenges still affected staff morale for instance salary inequality, transparency from both senior and top officials, lack of participation in decision making, quest for more engagement (Williams, 2010). Meanwhile, Schneider et al. (2013) emphasize that leadership should be at a center stage to ensure that a conducive working environment is provided to the institutional human resources. Tierney (1988) states that organizations hold their workers together if the mission is clear, values respected, procedures followed and above all strong talented human resources are retained. Therefore, institutional leadership should make plans clear, orient the new workers, and communicate frequently on the institutional progress to avoid unnecessary questions and gossiping among the staff. Hakkak et al. (2014) relate that organizational health can be observed through employee loyalty with high sprit of responsibility. This comes as a result of honor for work, trust and empowerment. Another study done by Lee et al. (2014) suggest that leadership should pay greater attention to health working environment so as to ease their work in regulating employee behaviors. Lesley et al. (2006) suggest that leadership should provide easy and understandable solutions to changes, provide key performance indicators, high basic proficiency in all the available practices and avoid conspicuous weakness since they can drag their future progress. Nobohar and Daneshfard (2016) in their study established that effective distribution of resource, cooperation and engagement among staff, ethics, effective communication and clear leadership styles, loyalty and commitment at individual basis, ranking, purpose consistency, performance and sprit and respect to institutional sprit are the influential factors of organizational health that any leadership and management must consider salient towards organizational effective performance and change. Yet Keller and Price (2010) in their model emphasize that direction, leadership, culture and climate, coordination and control, accountability, capability, external orientation, innovation and learning are the guiding framework towards organization's effective transformation and performance and above all leadership should be the pivotal point on which all the above items should rotate onto.

It can therefore be concluded that when educational institutions give the due attention towards health working environment, staff are likely to be rest assured of job security, merit promotion, attraction of talented young labour, excellent students outcome, avoidance of absenteeism and moonlighting, turnover, stress, poor quality services procrastination of duties and abs condiment (Nobohar and Daneshfard, 2016; Iljins et al., 2015; Lesley et al., 2006; Notario et al., 2014; Sokol et al., 2015; Tierney, 1988; Tiwari, 2014; Williams, 2010; Lin and Lin, 2014) we investigated the effect of organizational health culture on the organizational
EXAMINING ORGANIZATIONAL HEALTH PRACTICES

Miiro Farooq

Azam Othman

Mohamad Sahari Nordin

Mohd Burhan Ibrahim 
EXAMINING ORGANIZATIONAL HEALTH PRACTICES

Miiro Farooq

Azam Othman

Mohamad Sahari Nordin

Mohd Burhan Ibrahim effectiveness of health promotion. At the individual level, we adopted a crosslevel analysis to determine if organizational health culture affects employee effectiveness through the mediating effect of employee health behavior; Setting: The study setting consisted of the workplaces of various enterprises.; Subjects: We selected 54 enterprises in Taiwan and surveyed 20 full-time employees from each organization, for a total sample of 1011 employees.; Measures: We developed the Organizational Health Culture Scale to measure employee perceptions and aggregated the individual data to formulate organization-level data. Organizational effectiveness of health promotion included four dimensions: planning effectiveness, production, outcome, and quality, which were measured by scale or objective indicators. The Health Promotion Lifestyle Scale was adopted for the measurement of health behavior. Employee effectiveness was measured subjectively in three dimensions: self-evaluated performance, altruism, and happiness.; Analysis: Following the calculation of descriptive statistics, hierarchical linear modeling (HLM.

From the literature given above, the research problem and the conceptual framework of this study were developed. The study sought to establish the perceived underlying structure of organizational health constructs in the universities of the central region in Uganda. And this consisted of climate and culture, control and coordination, accountability, innovation and learning. It has been observed that there is no agreed scale and theory of measuring organizational health construct. This study moved with an expansion of the efforts of the conceptual framework done by (Hakkak et al., 2014; Iljins et al., 2015; Notario et al., 2014; Keller and Price, 2010; Sokol et al., 2015; Tiwari, 2014; Lin and Lin, 2014).

The rapid and unpredictable changes today place a lot of pressure on university existence vis-a-vis institutional transformation. The intensity of international rankings and competition are pressing universities to change from the known traditional scientific management approach to institutional performance (Yang, 2015). Moreover for the institutions to attain credible work and recognition, they must ensure that they have strong personnel with needed skills, knowledge and experience to enhance these institutions sustainable development and transformation in the era of competition (Ballerini and Ballerini, 2017; Nordin, 2011). However, these institutions cannot attain quality staff and performance without prior attendance to factors that influence organisational health (Nordin, 2011; Yang, 2015). Since organisational health plays a key role in institutional stability, learner achievement and societal goals, higher education leadership is supposed to play a greater role in ensuring that staff work under conducive and attractive environment so as to meet the stake holders expectations (Demİrtaş, 2015; Hayford, 2016; Penava, 2014). However, the situation in Uganda pertaining to the same issue is still worrisome with mushrooming universities without enough qualified human resource. This kind of situation has not only led to 
moonlighting among staff within these institutions, but has also attracted workers without minimum requirements of teaching in the universities (Altbach et al., 2009; Altbach, 2013; Zeelen, 2012). In addition universities are engulfed with strikes of both staff and students (Asiimwe and Steyn, 2013; Bailey et al., 2011; Bigabwenkya, 2013; Bunoti, 2011; Dushane, 2016; Freeman et al., 2010; Jacob, 2007, 2010; Kasozi et al., 2003; Kasozi, 2014; Liang, 2004; Mayer et al., 2014; Muwagga, 2011; Nabayego and Itaaga, 2014; NCHE, 2006; Oyo et al., 2008; Saymeh, 2014; Ssempebwa and Nakaiza, 2013; Ssentamu and Chancellor, 2013; Tettey, 2009; Tibarimbasa, 2010; de Weert, 2011).

The challenges cited above do not only affect universities but have also impacted greatly on Uganda's population in terms of un employment among graduates, lack of practical skills for inventory and self-development, corruption, merciless hearts, misappropriation of government projects and misbehaviour among the elite and professionals. It is on this basis that this study is under taken to examine the perceived organisational health practices among the universities in the central region of Uganda. The study intended to expound thoughts about the subdimensions of organizational health construct by covering the universities where staff perception was studied and added to the findings of previous studies. Since there has not been any study of this kind using structural equation modelling technique among the Ugandan universities, it gives the foundation and justification for currying out this research.

\subsection{Objectives of the study}

For purposes of addressing and examining the sub constructs of organizational health construct as perceived by university staff. The following research objectives were formulated:

1) To conceptualize the theoretical framework of organizational health sub dimensions;

2) To develop a questionnaire for measuring organizational health practices in universities;

3) To examine the levels of organizational health practices as perceived by staff in Ugandan universities.

\subsection{Hypotheses}

1) The highly practiced interconnected subconstructs of organizational health are four as perceived by staff among the universities in Uganda.

2) The perceived four subconstructs of organizational health questionnaire is psychometrically acceptable and comprehensive with regard to validity and reliability.

3) The hypothesized model is fit, reliable and valid for the data.
EXAMINING ORGANIZATIONAL HEALTH PRACTICES

Miiro Farooq Azam Othman Mohamad Sahari Nordin Mohd Burhan Ibrahim 
EXAMINING ORGANIZATIONAL HEALTH PRACTICES

Miiro Farooq

Azam Othman

Mohamad Sahari Nordin

Mohd Burhan Ibrahim

\section{Research methodology}

The study sample was attained from 820 university staff both full and part time. The groups involved were the academic and administrative staff from the level of teaching assistants and administrative assistants. The number was big because the study employed structure equation modeling technique for data analysis. Since this technique requires a big sample to provide reasonable estimates and requirements for acceptable model, stratified random sampling procedure was used to gather the required data of the study. Furthermore 2000 study questionnaires were directly distributed to the targeted staff among the six universities that participated in the study by the researcher and research assistants. Out of the 2000 research survey tools 847 were returned after the entire process of data collection. Moreover, through the process of data cleaning and scrutiny only 820 were filled properly. As it was envisaged while designing the study tool the big sample was fitting to address the requirements of employing confirmatory factor analysis (CFA) (Byrne, 2009; Kline, 2011; Livote and Wyka, 2009).

\subsection{Measurement}

To attain the required data for the descriptive study a questionnaire with 25 items was designed with a Likert scales ranging from strongly agree to strongly disagree. The subdimensions of organisational health considered were culture and climate, control and coordination, accountability and innovation/invention. To arrive at the needed findings, Amos Version 22 was employed through the use of structural equation modelling. Before administering the survey tool several experts both in the fields of research methodology and management were contacted to evaluate the validity of the questionnaire, the suggestions and modification were captured to conform to research standards. To arrive at both the minimum and maximum reliability of the questionnaire the Cronbach Alpha techniques were used and the indices were above the threshold of $(\alpha>.70)$, hence meeting the requirement of reliability as showed in the Table 1.

\section{Data analysis}

The Table below summarises the findings from descriptive analysis of the perceived organisational health practices by the staff in the six universities of the central in Uganda. The results show that generally there is positive application of the four multidimensional subconstructs of organisational health within these universities.

From the results indicated in the table above, it is clearly shown that the above subconstructs of organizational health construct met the criteria of validity and therefore qualify for further analysis through the use of confirmatory factor analysis. 


\begin{tabular}{|c|c|c|c|c|}
\hline Code & Dimension & Mean & $\begin{array}{c}\text { Std. } \\
\text { Deviation }\end{array}$ & $\begin{array}{l}\text { Cronbach } \\
\text { Alpha }\end{array}$ \\
\hline 1 & Culture and climate & & & .771 \\
\hline occ1 & $\begin{array}{l}\text { The university environment enables me to freely } \\
\text { interact with fellow staff and students }\end{array}$ & 3.75 & 1.155 & \\
\hline occ2 & $\begin{array}{l}\text { I feel free to share with university leadership and } \\
\text { staff my cultural beliefs, values and quality work } \\
\text { skills }\end{array}$ & 3.66 & 1.093 & \\
\hline occ3 & $\begin{array}{l}\text { I regularly attend university meetings to discuss } \\
\text { the university vision and mission }\end{array}$ & 3.55 & 1.156 & \\
\hline occ4 & $\begin{array}{l}\text { The university management and leadership handle } \\
\text { conflicts and disagreement with professionalism at } \\
\text { all levels }\end{array}$ & 3.52 & 1.105 & \\
\hline occ5 & $\begin{array}{l}\text { My daily workload is manageable due to suitable } \\
\text { and pleasant working environment at the university }\end{array}$ & 3.50 & 1.137 & \\
\hline occ6 & Staff are compensated adequately for the extra job & 3.35 & 1.188 & \\
\hline occ7 & $\begin{array}{l}\text { The daily business plan activities directly link } \\
\text { with the university culture and measured as per the } \\
\text { university mission and vision }\end{array}$ & 3.43 & 1.158 & \\
\hline occ8 & $\begin{array}{l}\text { I have the capacity to advise the university leader- } \\
\text { ship and staff to improve the standard of university } \\
\text { operations and services }\end{array}$ & 3.41 & 1.212 & \\
\hline 2 & Control and coordination & & & .752 \\
\hline $\operatorname{ccs} 2$ & $\begin{array}{l}\text { The university is against too much bureaucracy to } \\
\text { get something done }\end{array}$ & 3.33 & 1.221 & \\
\hline $\operatorname{ccs} 3$ & $\begin{array}{l}\text { The university schedules and plans for all its activi- } \\
\text { ties have helped me to ensure proper coordination } \\
\text { of activities }\end{array}$ & 3.53 & 1.158 & \\
\hline $\operatorname{ccs} 4$ & $\begin{array}{l}\text { The institutional leadership ensures that staff work } \\
\text { in coordinative and collective manner to achieve } \\
\text { the set goals }\end{array}$ & 3.54 & 1.099 & \\
\hline $\operatorname{ccs} 5$ & $\begin{array}{l}\text { Some of the university processes in place are } \\
\text { archaic and affect control and coordination of } \\
\text { activities }\end{array}$ & 3.50 & 1.110 & \\
\hline 3 & Accountability & & & .784 \\
\hline acc1 & $\begin{array}{l}\text { University managers effectively coordinate, resolve } \\
\text { problems and make decisions cross-functionally } \\
\text { rather than operate in functional silos }\end{array}$ & 3.45 & 1.108 & \\
\hline acc2 & $\begin{array}{l}\text { The university does not entertain unnecessary } \\
\text { duplication of work that cause inconvenience to } \\
\text { other departments }\end{array}$ & 3.54 & 1.069 & \\
\hline $\operatorname{acc} 3$ & $\begin{array}{l}\text { We are accountable collectively in coordination } \\
\text { to ensure the development and implementation of } \\
\text { both strategic and business plans }\end{array}$ & 3.48 & 1.116 & \\
\hline
\end{tabular}

EXAMINING ORGANIZATIONAL HEALTH PRACTICES

Miiro Farooq Azam Othman Mohamad Sahari Nordin Mohd Burhan Ibrahim 
EXAMINING

ORGANIZATIONAL

HEALTH PRACTICES

Miiro Farooq

Azam Othman

Mohamad Sahari Nordin

Mohd Burhan Ibrahim

Table 1.

continued

\begin{tabular}{|c|c|c|c|c|}
\hline Code & Dimension & Mean & $\begin{array}{c}\text { Std. } \\
\text { Deviation }\end{array}$ & $\begin{array}{l}\text { Cronbach } \\
\text { Alpha }\end{array}$ \\
\hline Acc 4 & $\begin{array}{l}\text { My poor performance is addressed through co- } \\
\text { aching at job and is always aligned without transfer } \\
\text { or termination }\end{array}$ & 3.46 & 1.167 & \\
\hline Acc5 & $\begin{array}{l}\text { I act accordingly as per the contracts to ensure that } \\
\text { education quality issues are my responsibility }\end{array}$ & 3.62 & 1.120 & \\
\hline Acc6 & $\begin{array}{l}\text { I take ownership in solving problems, with a focus } \\
\text { on forgiveness and learning instead of blaming } \\
\text { others }\end{array}$ & 3.67 & 1.055 & \\
\hline Acc7 & $\begin{array}{l}\text { Staff are served with evaluation feedback reports } \\
\text { from the students and other customers to improve } \\
\text { on their performance }\end{array}$ & 3.45 & 1.154 & \\
\hline Acc8 & $\begin{array}{l}\text { The university administration reprimands staff for } \\
\text { delays in executing their duties }\end{array}$ & 3.49 & 1.115 & \\
\hline 4 & Innovation/invention & & & .741 \\
\hline II1 & $\begin{array}{l}\text { Administration assures that a task-oriented atmo- } \\
\text { sphere is fostered in this university with the aim of } \\
\text { innovation }\end{array}$ & 3.40 & 1.131 & \\
\hline II 2 & $\begin{array}{l}\text { Innovative staff in the teaching of students receive } \\
\text { monetary or nonmonetary rewards }\end{array}$ & 3.39 & 1.193 & \\
\hline II 3 & $\begin{array}{l}\text { The university has a development or training plan } \\
\text { that can enhance staff in acquisition of new know- } \\
\text { ledge, ideas and skills initiated for better perfor- } \\
\text { mance standards }\end{array}$ & 3.40 & 1.143 & \\
\hline II4 & $\begin{array}{l}\text { The university takes steps to alter the monetary } \\
\text { rewards of a persistently inactive and non-innova- } \\
\text { tive staff. }\end{array}$ & 3.34 & 1.134 & \\
\hline II5 & $\begin{array}{l}\text { I and fellow staff initiate and execute change rather } \\
\text { than resisting or avoiding change }\end{array}$ & 3.51 & 1.066 & \\
\hline Total & & & & .901 \\
\hline
\end{tabular}

\subsection{Validity of organizational health subconstructs}

To attain the validity of organisational health construct, a confirmatory factor analysis (CFA) was run on the obtained data from the six universities. The score for factor loadings of all items for the subconstructs of organisational health construct were above the threshold 0.5 as indicated by the study findings. This was clear indication that the study findings have met the required estimates of structural equation modelling technique of data analysis (Byrne, 2009; Hershberger, 2003; Iacobucci, 2010; Jayasinghe-Mudalige et al., 2012; Kline, 2011; Livote and Wyka, 2009; Rosseel, 2012; Schreiber et al., 2006)researchers can specify confirmatory factor analysis models, regression models, and complex path models. We present the basic elements of a structural equation model, introduce the estimation 
technique, which is most often maximum Likelihood (ML. In addition, the findings from CFA of the four subconstructs of the hypothesized measurement model of organizational health tested well, whereby the fit indices in terms of variance-covariance matrix showed that $\mathrm{CFI}=.933, \mathrm{RMSEA}=.054, \mathrm{DF}=98$, $\mathrm{P}=.000, \mathrm{CMIN}=330.983$, and $\mathrm{CMIN} / \mathrm{DF}=3.377$. These parameters of the study estimates were statistically significant, this was reflected in the magnitude and directions of the factor loadings as showed in the figure below.

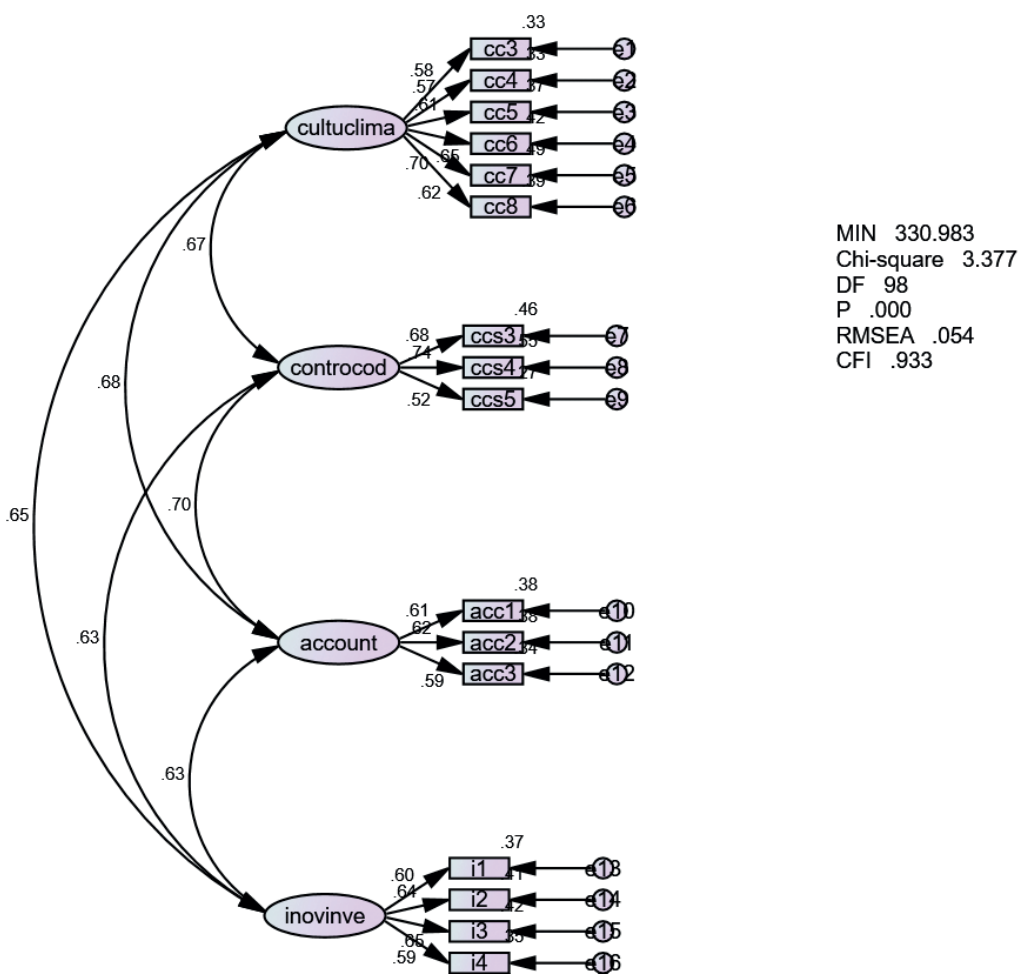

Figure 1. Organizational health construct measurement model

However, when the study factor loadings were analyzed further to indicate both the convergent and discriminant validity, some of the factor loadings were below the minimum requirement hence, necessitating the elimination of one construct accountability from the measurement model after re-examination of the items of the variable as indicated in the Figure 1.

The results from the re-specified measurement model reflected that it is only three factors that measure organizational health instead of four as indicated before and thus strengthening the required model goodness fit with CFI $=.974$, RMSEA $=.054, \mathrm{DF}=32, \mathrm{P}=.000, \mathrm{CMIN}=83.119$, and $\mathrm{CMIN} / \mathrm{DF}=2.596$. Hence on the basis of the RMSEA and CFI measure, the model is judged to have an acceptable fit. All measures associated with the construct are statistically significant. 
EXAMINING

ORGANIZATIONAL

HEALTH PRACTICES

Miiro Farooq

Azam Othman

Mohamad Sahari Nordin

Mohd Burhan Ibrahim

Figure 2.

Re-specified organizational health construct measurement model

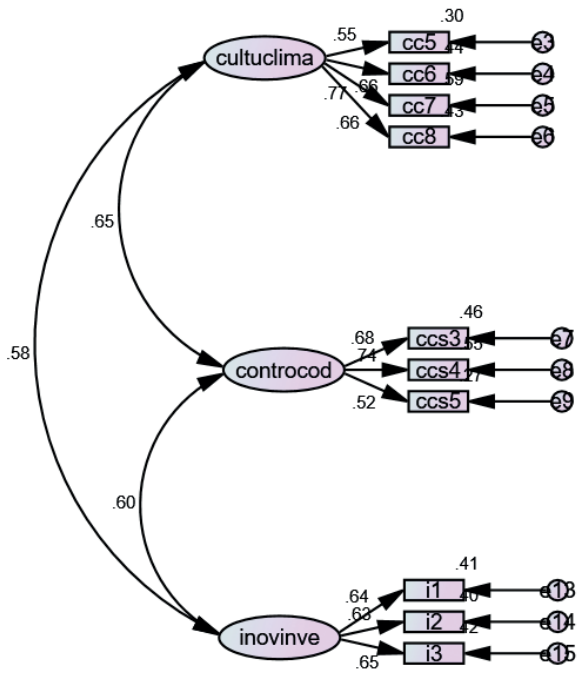

CMIN 83.119

Chi-square 2.597

DF 32

P. .000

RMSEA .044

CFI .974

Table 2.

Organizational

Health measurement model

\begin{tabular}{llll}
\hline Dimension/construct & $\mathbf{1}$ & $\mathbf{2}$ & $\mathbf{3}$ \\
\hline Culture and climate & .44 & .42 & .34 \\
\hline Control and coordination & .65 & .43 & .36 \\
\hline Innovation and invention & .58 & .60 & .41 \\
\hline Composite Reliability & .75 & .70 & .70 \\
\hline
\end{tabular}

$N B$. The values shown diagonally above are the average variance extracted (AVEs) for individual sub-dimension; and under the diagonal is the correlation matrix; whereas, the shared variance matrix is above the diagonal.

\section{Conclusions}

The study was developed to explore the university staff's perception towards organisational health practices among the universities that have been in place for the period of fifteen (15) years and above. The study findings reflected that there is so far, some positive institutionalisation of organisational health practices within the universities though there are still challenges of stabilising the staff into the systems to work diligently towards institutional transformation.

Organisational health is a key aspect that reflects organisational development and progress. Most of the public universities in Uganda in the past have been so dependent on government funding until the relatively recent liberalisation of education that opened doors to the private sector. With this kind of competition among the private and public universities, higher education institutions are 
embarking on the utilisation of their autonomy to change the internal organisational structures, hence opening up their eyes to pay more attention to organisational health practices. In addition, the global forces that call for leadership and stakeholders to invest more of the institutions' resources in organisational health consequently have influenced Ugandan universities to start their movements away from the known scientific traditional management to organisational effective performance. Ugandan universities have no option except to accept the needs of the time and implement several practices of this construct such that they compete favourably on the international scene. Universities should seek for trajectories through the use of ambidextrous means to attain the ingenuity of pursuing excellent teaching, research and innovation as part of their reform agendas to address the needs of the society. Therefore, organisational health as perceived by university staff is a critical issue that the current higher education reforms in Uganda must take seriously to improve on the universities effective performance both at local and international levels.

The results of the study suggest that universities in Uganda should pay more attention to the concept of effective performance so as to attain standards of developing staff and retain them at the same time so as to compete favourably. However, implementing a conducive working environment for staff may not be easy to handle at once. Universities should find out a mechanism of attracting highly qualified staff and ensure that they are provided with the reasonable facilitation to serve the institutions with diligence and commitment.

\section{References}

Abdul-Jalal, H., Toulson, P., Tweed, D. (2013), "Knowledge Sharing Success for Sustaining Organizational Competitive Advantage", Procedia Economics and Finance, Vol. 7, pp. 150-157. DOI: 10.1016/S2212-5671(13)00229-3

Abrey, M., Smallwood, J.J. (2014), “The effects of unsatisfactory working conditions on productivity in the construction industry", Procedia Engineering, Vol. 85, pp. 3-9. DOI: $10.1016 /$ j.proeng.2014.10.522

Altbach, P. (2013), The international imperative in higher education, SensePublishers. DOI: $10.1007 / 978-94-6209-338-6$

Altbach, P.G., Reisberg, L., Rumbley, L.E. (2009), Trends in Global Higher Education: Tracking an Academic Revolution Trends in Global Higher Education: Tracking an Academic Revolution, UNESCO.

Altindis, S. (2011), "Job motivation and organizational commitment among the health professionals: A questionnaire survey", African Journal of Business Management, Vol. 5 No. 21, pp. 8601-8609. DOI: 10.5897/AJBM11.1086

Anderson, C., Brown, C.E. (2010), "The functions and dysfunctions of hierarchy", Research in Organisational Behavior, Vol. 30., pp. 1-35. DOI: 10.1016/j.riob.2010.08.002

Asiimwe, S., Steyn, G. (2013), "Obstacles Hindering the Effective Governance of Universities in Uganda”, Journal of Social Sciences, Vol. 34 No. 1, pp. 17-27. 
EXAMINING ORGANIZATIONAL HEALTH PRACTICES

Miiro Farooq Azam Othman Mohamad Sahari Nordin Mohd Burhan Ibrahim
Bailey, T., Cloete, N., Pillay, P. (2011), Universities and Economic Development in Africa. Case Study: Kenya and University of Nairobi, Centre for Higher Education Transformation, Wynberg.

Ballerini, V. (2017), "Global higher education trends and national policies: access, privatization, and internationalization in Argentina", Policy Reviews in Higher Education, Vol. 1 No. 1, pp. 42-68. DOI: 10.1080/23322969.2016.1245113

Bauer, G.F., Jenny, G.J. (2012), "Moving towards positive organisational health: challenges and a proposal for a research model of organisational health development", in: Houdmont J., Leka S., Sinclair R. (Eds.), Occupational Health Psychology: European Perspectives on Research, Education and Practice, Wiley-Blackwell, Oxford, pp. 126-145.

Bigabwenkya, S. (2013), Public University Education: An Analysis of Capability Expansion Among Students In Uganda, University of South Africa, Pretoria.

Bunoti, S. (2011), "The Quality of Higher Education in Developing Countries Needs Professional Support", paper presented at the $22^{\text {nd }}$ International Conference on Higher Education, available at: http://www.intconfhighered.org/FINAL Sarah Bunoti.pdf (accessed 13 August 2017).

Byrne, B.M. (2009), "Structural Equation Modeling with AMOS. Basic Concepts, Application, and Programming", available at: http://www15.uta.fi/arkisto/aktk/lectures/ sem_en/pdf/sem_exercise_v2.5.pdf (accessed 15 June 2017).

Cameron, K. (1978), "Measuring Organizational Effectiveness in Institutions of Higher Education", Administrative Science Quarterly, Vol. 23 No. 4, pp. 604-632. DOI: $10.2307 / 2392582$

Demİrtaş, Z. (2015), "The Relationship Between Job Satisfaction and Organizational Commitment: A Study on Elementary Schools", Kastamonu Education Journal, Vol. 23 No. 1, pp. 253-268.

Dewar, C., Blackburn, S., Nielsen, A.B., Irons, E., Scott, K., Meaney, M., Ulosevich, G., Wood, C. (2011), How do I transform my organization's performance?, McKinsey and Company.

Dushane, G. (1956), "Higher Education", Science, Vol. 124 No. 3232.

Eduan, S.A., Ssempebwa, J., Nakaiza, J., Eduan, W., Nkata, J.L., Musaazi, J.C.S. (2012), "Why are Reform Initiatives in East African Universities Failing? Evidence from the Case of Makerere University", Journal of Educational Review, Vol. 5 No. 4, pp. 521-529.

Freeman, P., Johansson, E., Thorvaldsson, J. (2010), Enhancing Research Capacity at Makerere University, Uganda through collaboration with Swedish Universities, 2000-2008, Sida, Sweden.

Guidetti, G., Converso, D., Viotti, S. (2015), "The School Organisational Health Questionnaire: Contribution to the Italian Validation", Procedia - Social and Behavioral Sciences, Vol. 174, pp. 3434-3440. DOI: 10.1016/j.sbspro.2015.01.1015

Hakkak, M., Pirzad, A., Nasab, M.S., Arefnejad, M. (2014), "Investigates relation between organizational health and employee empowerment (Yasouj University case study)", Applied Mathematics in Engineering, Management and Technology, Vol. 2 No. 2, pp. 408-415. 
Hashim R., Hattori M. (Eds.) (2015), Critical Issues and Reform in Musim Higher Education, ILUM Press, Malaysia, Kuala Lumpur.

Hayford, A. (2016), "Internal Branding and the Competitive Performance of Private Universities in Ghana", Journal of Competitiveness, Vol. 8 No. 3, pp. 22-37. DOI: 10.7441/joc.2016.03.02

Hershberger, S.L. (2003), "The Growth of Structural Equation Modeling: 1994-2001", Structural Equation Modeling: A Multidisciplinary Journal, Vol. 10 No. 1, pp. 35-46. DOI: 10.1207/S15328007SEM1001_2

Hong K.-S., Law, L., Toner, A.M. (2014), "Organizational Health: A Study of a Malaysian Private Higher Learning Institution”, International Journal of Business and Society, Vol. 15 No. 2, pp. 277-302.

Husain, Z. (2013), "Effective communication brings successful organizational change", The Business \& Management Review, Vol. 3 No. 2, pp. 43-50.

Iacobucci, D. (2010), "Structural equations modeling: Fit Indices, sample size, and advanced topics", Journal of Consumer Psychology, Vol. 20 No. 1, pp. 90-98. DOI: 10.1016/j.jcps.2009.09.003

Iljins, J., Skvarciany, V., Gaile-Sarkane, E. (2015), "Impact on Organizational Climate trough Organizational Culture factors. Case Study of Latvia and Lithuania", Trendy Ekonomiky a Managementu/Trends Economics and Management, Vol. 9 No. 24, pp. 9-17.

Jacob, M. (2007), Research funding instruments and modalities: Implication for developing countries, Programme on Innovation, Higher Education and Research for Development (IHERD).

Jacob, M. (2010), Research funding instruments and modalities: Implication for developing countries, IHERD, Lund University, Sweden.

Jafarzadeh, M. (2015), "A survey on the Relation between Organizational Health and Organizational Learning across Iran", Research Journal of Recent Sciences, Vol. 4 No. 2, pp. 20-24.

Jayasinghe-Mudalige, U.K., Udugama, J.M.M., Ikram, S.M.M. (2012), "Use of Structural Equation Modeling Techniques to Overcome the Empirical Issues Associated With Quantification of Attitudes and Perceptions", Sri Lankan Journal of Applied Statistics, Vol. 13, pp. 15-37.

Jenaabadi, H., Zare Javan, Z. (2014), "Study Of The Relationship Between Organizational Health and Establishment of School-Based Management in Secondary Schools of The City of Chabahar City, Iran", International Journal of Economy, Management and Social Sciences, Vol. 3 No. 6, pp. 311-316.

Kafraj, M.M., Gholifar, E., Rezvanfar, A. (2013), "Recognizing organizational variables affecting organizational health of Iranian agricultural colleges", African Journal of Business Management, Vol. 7 No. 16, pp. 1445-1451. DOI: 10.5897/AJBM11.1479

Kasozi, A.B.K., Musisi, N.B., Nakayiwa, F., Balihuta, A., Katunguka, S. (2003), The Uganda Tertiary/Higher Education Unit Cost study, Makerere Institute of Social Research, Kampala.

Kasozi, A.B.K. (2014), "Trends in Higher Education Regulation in sub-Saharan Africa", International Higher Education, Vol. 75, pp. 1-5.
EXAMINING ORGANIZATIONAL HEALTH PRACTICES

Miiro Farooq Azam Othman Mohamad Sahari Nordin Mohd Burhan Ibrahim 
EXAMINING ORGANIZATIONAL HEALTH PRACTICES

Miiro Farooq

Azam Othman

Mohamad Sahari Nordin

Mohd Burhan Ibrahim
Kline, R.B. (2011), Principles and Practices of Structural Equation Modeling, The Guilford Press, New York.

Lee, J.-C., Chen, C.-L., Xie, S.-H. (2014), “The Influence of School Organizational Health and Occupational Burnout on Self-perceived Health Status of Primary School Teachers", Procedia - Social and Behavioral Sciences, Vol. 116, pp. 985-989. DOI: 10.1016/j.sbspro.2014.01.332

Lejeune, C., Vas, A. (2009), "Organizational culture and effectiveness in business schools: a test of the accreditation impact", Journal of Management Development, Vol. 28 No. 8, pp. 728-741. DOI: 10.1108/02621710910985504

Lesley, K., Loch, M., Schaninger, W. (2006), "Managing your organization by the evidence", The McKinsey Quarterly, Vol. 3, pp. 65-75.

Liang, X. (2004), Uganda Tertiary Education Sector Report, Africa Region Human Development Working Paper Series, The World Bank, Washington.

Lin, Y.-W., Lin, Y.-Y. (2014), "A multilevel model of organizational health culture and the effectiveness of health promotion", American Journal of Health Promotion, Vol. 29 No. 1, pp. 53-63. DOI: 10.4278/ajhp.121116-QUAN-562

Livote, E.E., Wyka K.E. (2009), "Introduction to Structural Equation Modeling Using SPSS and AMOS. Niels J. Blunch. Thousand Oaks, CA: Sage, 2008, 270 pages, \$39.95", Structural Equation Modeling: A Multidisciplinary Journal, Vol. 16 No. 3, pp. 556-560. DOI: 10.1080/10705510903008345

Keller, S., Price, C. (2010), "Performance and Health: An evidence-based approach to transforming your organisation”, The McKinsey Quarterly.

Mayer, P., Wilde, M., Dinku, A., Fedrowitz, J., Shitemi, N. L., Wahlers, M., Ziegele, F. (Eds.) (2011), Challenges for faculty management at African higher education institutions, University of Applied Sciences, Osnabrück.

Mpaata, A.K. (2010), University competitiveness through quality assurance: The challenging battle for intellectuals, Kampala.

Muwagga, A.M. (2011), "Reflections on the philosophy behind the different universities in Uganda", Educational Research, Vol. 2 No. 1, pp. 736-744.

Nabayego, C., Itaaga, N. (2014), "How University Education in Uganda Can Be Improved To Prepare Economically Productive Graduates", Asian Journal of Social Sciences, Vol. 1 No. 2, pp. 62-70.

Natario, M.M., Araujo, C.S., Couto, J.P.A. (2014), "Higher Education Institution Organizational Climate Survey", International Journal of Advances in Management and Economics, Vol. 3 No. 1, pp. 107-121.

NCHE (2006), The state of higher education and training in Uganda 2011: a report on higher education delivery and institutions, Kampala, available at: http://www. unche.or.ug/wp-content/uploads/2014/04/The-State-of-Higher-Education-2011.pdf (accessed 21 June 2017).

Nicolay, C.R. (2011), The Oregon Health Plan - Health (San Francisco).

Nobohar, H. Daneshfard, K. (2016), "The Identification of Influencial Factors on Organisational Health in the Tehran Municipality Located in Zone 9", International Business Management, Vol. 10 No. 6, pp. 1026-1032.

Nordin, N. (2011), “The Influence of Emotional Intelligence, Leadership Behaviour and Organizational Commitment on Organizational Readiness for Change in Higher Learn- 
ing Institution", Procedia - Social and Behavioral Sciences, Vol. 29, pp. 129-138. DOI: 10.1016/j.sbspro.2011.11.217

Oyo, B., Williams, D., Barendsen, E. (2008), “A System Dynamics Tool for Higher Education Funding and Quality Policy Analysis", in: Proceedings of the 2008 International Conference of the System Dynamics Society, Greece, Athens, July 20-24, available at: https://www.systemdynamics.org/conferences/2008/proceed/papers/OYO314.pdf (accessed 20 June 2017).

Penava, S. (2014), "The Relevance of Transformational Leadership in Shaping Employee Attitudes Towards”, Economic Annals, Vol. LIX No. 200, pp. 131-162. DOI: 10.2298/ EKA1400131P

Porter-O'Grady, T., Malloch, K. (2002), Quantum Leadership: A Textbook of New Leadership, Jones \& Barlett Publishers, Sudbury.

Porter-O'Grady, T, Malloch, K. (2015), Quantum Leadership: Building Better Partnerships For Sustainable Health (4 ${ }^{\text {th }}$ Edition), MA: Jones \& Bartlett, Burlington.

Rosseel, Y. (2012), "Lavaan: An R Package for Structural Equation”, Journal of Statistical Software, Vol. 48 No. 2, pp. 1-36. DOI: 10.18637/jss.v048.i02

Sarghin, A.E. (2016), "Surveying the influence of organizational learning on strategic flexibility, competitive strategies and organizational performance", Journal of Administrative Management, Education and Training, Vol. 12 No. 2, pp. 151-157.

Saymeh, A.A.F. (2014), "Higher Education and Scientific Research of Third World Countries Need Professional Support: Case of Jordan", Education Journal, Vol. 3 No. 4, pp. 245-255. DOI: 10.11648/j.edu.20140304.17

Schneider, B., Ehrhart, M.G., Macey, W.H. (2013), "Organizational Climate and Culture”, The Annual Review of Psychology, Vol. 64, pp. 361-388. DOI: 10.1146/annurevpsych-113011-143809

Schreiber, J.B., Stage, F.K., King, J., Nora, A., Barlow, E.A. (2006), "Modeling and Confirmatory Factor Analysis Results: A Review", The Journal of Educational Research, Vol. 99 No. 6, pp. 323-338. DOI: 10.3200/JOER.99.6.323-338

Schuyler, K.G. (2004), “The Possibility of Healthy Organizations: Toward a New Framework for Organizational Theory and Practice", Journal of Applied Social Science , Vol. 21 No. 2, pp. 57-79. DOI: 10.1177/19367244042100203

Sokol, A., Gozdek, A., Figurska, I., Blaskova, M. (2015), "Organizational climate of higher education institutions and its implications for the development of creativity", Procedia - Social and Behavioral Sciences, Vol. 182, pp. 279-288. DOI: 10.1016/j. sbspro.2015.04.767

Ssentamu, J.D., Chancellor, V. (2013), Prospects and Challenges of Higher Education in Uganda, Kampala.

Tettey, W.J. (2009), Deficits in academic staff capacity in Africa and challenges of developing and retaining the next generation of academics, Calgary, Alberta.

Tibarimbasa, A. (2010), Factors affecting the Management of Private Universities in Uganda, University of Makarere, pp. 253. Retrieved from: https://news.mak.ac.ug/ documents/Makfiles/theses/Tibarimbasa_Avitus.pdf

Tierney, W.G. (1988), “Organizational Culture in Higher Education”, The Journal of Higher Education, Vol. 1 No. 59. DOI: 10.2307/1981868

Tiwari, U. (2014), “Organisational Climate in Higher Education Institutions of Madhya
EXAMINING ORGANIZATIONAL HEALTH PRACTICES

Miiro Farooq Azam Othman Mohamad Sahari Nordin Mohd Burhan Ibrahim 
EXAMINING ORGANIZATIONAL HEALTH PRACTICES

Miiro Farooq

Azam Othman

Mohamad Sahari Nordin

Mohd Burhan Ibrahim
Pradesh", Abhinav International Monthly Refereed Journal of Research in Management \& Technology, Vol. 3 No. 10, pp. 1-6.

Weert, E. (2011), Perspectives on Higher Education and the labour market: review of international policy developments, Centre for Higher Education Policy Studies, Enschede.

Williams, D.A. (2010), Campus Climate \& Culture Study: Taking Strides Towards a Better Future, Florida Gulf Coast University, USA.

Xenidis, Y., Theocharous, K. (2014), "Organizational health: Definition and assessment", Procedia Engineering, Vol. 85, pp. 562-570. DOI: 10.1016/j.proeng.2014.10.584

Yang, C. (2015), “The Effects of Higher Education's Institutional Organizational Climate on Performance Satisfaction: Perceptions of University Faculty in Taiwan", International Business Research, Vol. 8 No. 8, pp. 103-117. DOI: 10.5539/ibr.v8n8p103

Yüceler, A., Doğanalp, B., Kaya, Ş. D., Prof, A., Yüceler, A. (2013), "The Relation Between Organizational Health and Organizational Commitment", Mediterranean Journal of Social Sciences, Vol. 4 No. 10, pp. 781-788. DOI: 10.5901/mjss.2013. $\mathrm{v} 4 \mathrm{n} 10 \mathrm{p} 781$

Zeelen, J. (2012), "Universities in Africa: Working on Excellence for Whom? Reflections on Teaching, Research, and Outreach Activities at African Universities", International Journal of Higher Education, Vol. 1 No. 2, pp. 157-165. DOI: 10.5430/ijhe.v1n2p157 